\title{
Commentary: A bacterial global regulator forms a prion
}

\author{
Giovanni Di Guardo * \\ Faculty of Veterinary Medicine, University of Teramo, Teramo, Italy
}

Keywords: Clostridium botulinum, prions, amyloid, bacterial inheritance, bacteria, yeasts, prokaryotes, eukaryotes

\section{A commentary on}

\author{
A bacterial global regulator forms a prion \\ by Yuan, A. H., and Hochschild, A. (2017). Science 355, 5724-5733. doi: 10.1126/science.aai7776
}

OPEN ACCESS

Edited by:

Frank T. Robb,

University of Maryland, Baltimore,

USA

Reviewed by:

Santosh Kumar C. M.,

National Centre for Cell Science, India

*Correspondence: Giovanni Di Guardo gdiguardo@unite.it

Specialty section: This article was submitted to Evolutionary and Genomic Microbiology,

a section of the journal

Frontiers in Microbiology

Received: 22 January 2017 Accepted: 27 March 2017 Published: 11 April 2017

Citation:

Di Guardo G (2017) Commentary: A bacterial global regulator forms a prion. Front. Microbiol. 8:620. doi: 10.3389/fmicb.2017.00620
The recently reported identification, within the transcription terminator Rho of Clostridium botulinum ( $\mathrm{Cb}$-Rho), of a prion-like domain functionally similar to that of a yeast prion-forming protein, along with the amyloidogenicity conferred by it on $C b$-Rho, represent findings of extraordinary scientific relevance (Yuan and Hochschild, 2017). In this respect, another recent study has shown that lactic acid, a common bacterial metabolite, is a powerful inducer in yeast cells of $\left[G A R^{+}\right]$, a prion-like genetic element allowing the simultaneous metabolism of glucose and other carbon sources (Garcia et al., 2016). Still noteworthy, while synthetic mammalian prions were successfully generated in Escherichia coli bacteria (Legname et al., 2004, 2005), the amyloid$ß$ peptide-a protein crucially involved in Alzheimer's disease pathogenesis-has been recently reported to bind and trap bacterial pathogens inside the brain, thereby behaving like a natural antibiotic (Kumar et al., 2016). Furthermore, the normal host's cellular prion protein $\left(\mathrm{PrP}^{\mathrm{C}}\right)$ has been also shown to play a pivotal role in Brucella abortus infection of murine macrophages, with no evidence of bacterial colonization nor replication in cells from $\operatorname{PrP}^{\mathrm{C}}$-deficient mice (Aguzzi and Hardt, 2003; Watarai et al., 2003).

Although no doubts seem to exist that, based upon the results of the elegant work (Yuan and Hochschild, 2017) which is being addressed by the present commentary, $C b$-Rho acts like a prion-like element of inheritance in bacteria, I do not feel entirely confident about the Authors' conclusion, "suggesting that the emergence of prions predates the evolutionary split between eukaryotes and bacteria" (Yuan and Hochschild, 2017). As a matter of fact, although this would appear to be absolutely plausible from a biological standpoint, prior evidence of similar, or related prion-like domains in Rho or Rho-like proteins from other Clostridium genus members should be obtained to justify the Authors' statement. In this respect, Clostridium (C.) baratii, C. butyricum, and C. tetani, which are phylogenetically related to C. botulinum (Collins and East, 1998), could represent valuable "first choices" for "comparative" investigations of this kind. Finally, the priondriven, putative evolutionary links between bacterial and eukaryotic cells could gain additional insights from the study of mitochondria, ubiquitous cytoplasmic organelles derived from an alphaproteobacterial endosymbiont, which were acquired in the course of eukaryogenesis (Poole and Gribaldo, 2014).

\section{AUTHOR CONTRIBUTIONS}

After having carefully read the recent Science article by Drs. Yuan and Hochschild, upon which this manuscript is commenting, the Author (GD) has autonomously and independently written the present Commentary. 


\section{REFERENCES}

Aguzzi, A., and Hardt, W.-D. (2003). Dangerous liaisons between a microbe and the prion protein. J. Exp. Med. 198, 1-4. doi: 10.1084/jem.20030732

Collins, M. D., and East, A. K. (1998). Phylogeny and taxonomy of the food-borne pathogen Clostridium botulinum and its neurotoxins. J. Appl. Microbiol. 84, 5-17. doi: 10.1046/j.1365-2672.1997.00313.x

Garcia, D. M., Dietrich, D., Clardy, J., and Jarosz, D. F. (2016). A common bacterial metabolite elicits prion-based bypass of glucose repression. Elife 5:e17978. doi: 10.7554/eLife.17978

Kumar, D. K., Choi, S. H., Washicosky, K. J., Eimer, W. A., Tucker, S., Ghofrani, J., et al. (2016). Amyloid- $\beta$ peptide protects against microbial infection in mouse and worm models of Alzheimer's disease. Sci. Transl. Med. 8:340ra72. doi: 10.1126/scitranslmed.aaf1059

Legname, G., Baskakov, I. V., Nguyen, H. O., Riesner, D., Cohen, F. E., DeArmond, S. J., et al. (2004). Synthetic mammalian prions. Science 305, 673-676. doi: 10.1126/science.1100195

Legname, G., Nguyen, H. O., Baskakov, I. V., Cohen, F. E., Dearmond, S. J., and Prusiner, S. B. (2005). Strain-specified characteristics of mouse synthetic prions. Proc. Natl. Acad. Sci. U.S.A. 102, 2168-2173. doi: 10.1073/pnas.0409079102
Poole, A. M., and Gribaldo, S. (2014). Eukaryotic origins: How and when was the mitochondrion acquired? Cold Spring Harb. Perspect. Biol. 6:a015990. doi: 10.1101/cshperspect.a015990

Watarai, M., Kim, S., Erdenebaatar, J., Makino, S., Horiuchi, M., Shirahata, T., et al. (2003). Cellular prion protein promotes Brucella infection into macrophages. J. Exp. Med. 198, 5-17. doi: 10.1084/jem.20021980

Yuan, A. H., and Hochschild, A. (2017). A bacterial global regulator forms a prion. Science 355, 198-201. doi: 10.1126/science.aai7776

Conflict of Interest Statement: The author declares that the research was conducted in the absence of any commercial or financial relationships that could be construed as a potential conflict of interest.

Copyright (C) 2017 Di Guardo. This is an open-access article distributed under the terms of the Creative Commons Attribution License (CC BY). The use, distribution or reproduction in other forums is permitted, provided the original author(s) or licensor are credited and that the original publication in this journal is cited, in accordance with accepted academic practice. No use, distribution or reproduction is permitted which does not comply with these terms. 